\title{
Toward an Appropriate Model for Corporate Governance in Banking Industry- Case Study of Iran
}

\author{
Bita Mashayekhi, Alemeh Yazdanian, Farzaneh Jalali \\ Accounting Department, Faculty of Management, University of Tehran, Tehran, Iran \\ Email address: \\ mashaykhi@ut.ac.ir (B. Mashayekhi), almyazdanian@ut.ac.ir(A. Yazdanian), fajalali@ut.ac.ir (F. Jalali)
}

\section{To cite this article:}

Bita Mashayekhi, Alemeh Yazdanian, Farzaneh Jalali. Toward an Appropriate Model for Corporate Governance in Banking IndustryCase Study of Iran. International Journal of Business and Economics Research. Vol. 3, No. 2, 2014, pp. 108-117.

doi: $10.11648 /$ j.ijber.20140302.18

\begin{abstract}
Given the vital role of banks and other financial institutions in financial and economic stability, and also their great vulnerability to the potential imperfections of corporate governance and the need to maintain the depositors' funds and the stakeholders' interests, the issue of corporate governance and eliminating its weaknesses and failures are extremely important in banking industry. In recent financial scandals and economic crises which banks and other financial institutions have had a leading role because of malfunctioning of their corporate governance mechanisms. Furthermore, in 2011, the occurrence of a massive financial embezzlement and existence of enormous deferred bank accounts in Iran banking system implies that there is a serious failure in banks' corporate governance for the experts in this field.Therefore this study attempts to prepare information about the current state of corporate governance in Iran banks and compares it with that of prosperous big banks in other parts of the world. Additionally, it is going to investigate the weak points of corporate governance in Iran banks in order to present an appropriate model for them. It also should be noted that we review all available related documents in Iran banks and interview the managers and experts to obtain valid feedbacks in this regard. Then, we review successful and unsuccessful experiences of famous international banks such as Bank of America, TorontoDominion Bank, J. P. Morgan, and HSBC, and their corporate governance structures to extract and model them. By comparing this model with those belonging to Iran banks we can realize almost any weakness existing in Iran banks. Finally we suggest an appropriate model for Iran banks to improve the efficiency and effectiveness of the mechanism of their corporate governance.
\end{abstract}

keywords: Corporate Governance, Banking Industry, Iranian Banks, Model for Corporate Governance of Banks, Big International Banks, Financial Crisis

\section{Introduction:}

The late 1990's financial crisis in East Asia which included all financial and economic markets of main Asian countries was not only because of unsound management of macroeconomics, weaknesses of economic structures or drastic economic shocks, but also because of corporate governance failures in monetary and financial institutions, as many analysts and experts believe. When banks were affected by political upheaval, systemic risks and other dangers intensified; also, evident malfunctions in management and the lack of board of directors and senior management accountability and responsibility made crisis spread. So the cost of failures in corporate governance was crisis extension. In Indonesia, the most affected country by 1990 's crisis, government commitments to private banks exceeded $100 \%$ of GDP. Furthermore, financial crisis generated severe recession, rising poverty, social and political stability menace of East Asia counties. Corporate governance failures did not restrict the emerging markets and incorporated many independent states of the former Soviet which suffered from weaknesses in corporate governance. Corporate governance imperfections even through hiding information and weak monitoring and control on information release, caused famous companies including Enron, WorldCom etc. encounter the sever crises. It should be noted that in all recent financial scandals and economic crises which banks and other financial institutions have had a leading role, and always attention has been drawn towards the causative factor or factors that one of the main culprit was failures in corporate governance. In addition, in 2011, the occurrence of a 
massive financial embezzlement in Iranian banking system amounting to three billion dollars and existence of enormous deferred bank accounts which exceeds 100 billion dollars have led to this question: what caused these issues? One of the main factors considered by many banking experts including the head of the Central Bank of the Islamic Republic of Iran (CBIRI) has been the weakness in corporate governance mechanisms.

The recent academic and theoretical studies find out poor corporate governance mechanisms of banks as the main cause of the recent financial crises and attempts to present suggestions to solve the problems [1] [3] [5][2][4]. Failures in corporate governance, on the other hand, prompted much investigation into question of differences between banks from ordinary firms which are important in terms of corporate governance [5][6]. So, the different nature of banks from ordinary firms as well as vital role of banks in recent financial crises require think of presenting an appropriate model for corporate governance of banks. Considering macro embezzlement and other problems in Iran and the importance of corporate governance for banks, this study aims to present a suitable model for corporate governance of banks.

Against this background, the rest of this paper is organized as follows: following this introduction is literature review emphasizing on importance of corporate governance for banks and specific characteristics of banks, followed by methodology (research questions development and data collection). An explanation of the findings emphasizing on description of current state of corporate governance in Iranian banks is presented and the appropriate model for banks' corporate governance is raised in discussion section. Finally the conclusion of this paper is discussed.

\section{Literature Review}

In economic and financial crises which have occurred in recent years, banks and other financial intermediation institutions, like other big manufacturing and service companies, have been at the center of the crises, so that this issue caused bankruptcy of many banks in all around the world. Corporate governance failures have been known as a main factor of recent financial crises. Previous research has emphasized that corporate governance is one of the vital concern of all financial institutions especially banks [6]. International experiences also clearly demonstrate that corporate governance mechanisms are of the modern managerial tools which can restrain mentioned dangers. Corporate governance, also, is considered as the most significant method for preventing companies especially banks from facing corruption. The Basel Committee on Banking Supervision (BCBS) as an international committee of banking supervisory argues:

"Given the important financial intermediation role of banks in an economy, the public and the market have a high degree of sensitivity to any difficulties potentially arising from any corporate governance shortcomings in banks. Corporate governance is thus of great relevance both to individual banking organizations and to the international financial system as a whole, and merits targeted supervisory guidance" [2].

Therefore this committee is always attempting to promote sound corporate governance practices for banking industry [2], to assist banking supervisors to adopt sufficiently suitable corporate governance mechanisms by banking organizations in their own countries.

Given the different nature of banks from other companies, it is vitally important to consider special characteristics of banks to present desirable corporate governance model for banking organizations. Since banks are dealing with economic and financial activities, they easily expose to different kinds of risks including operational, liquidity, credit and other risks. Factors such as lack of consistent combination of operational assets and debts in terms of size and maturity, interest rate with increasing internal and operational costs, reduction of cash earnings and lack of an appropriate system for risk control are existent and potential dangers to lead banks to crisis. Among the characteristics that are known for banks and thus distinguish them from other companies, the following can be noted:

1. The stakeholders of banks are much more than nonfinancial firms [5]. Hamid Mehran, Alen Morrison and Joel Shapiro (2011) argue: "Besides shareholders, the stakeholders in banks are both numerous (depositors, debt holders, and the government as both insurers of deposits and residual claimant on systemic externalities) and large (over 90 percent of the balance sheet of banks is debt)".

2. Hamid Mehran, Alen Morrison and Joel Shapiro (2011) claim that the business of banks is ambiguous and complicated and quickly changed[5].

3. The liquidity producing function of banks is totally different from ordinary firms that it would be the result of mismatch between the maturity of the two sides of banks' balance sheets (assets and liabilities) [6].

4. Banks most commonly use leverage. The maturity mismatch between banks' assets and liabilities compensate for a premium charged to creditors, i.e., a bank's creditors have to pay a higher interest rate than the bank pays for its refinancing [6].

5. Since banks' balance sheets represent assets such as Asset-Backed Securities (ABSs), Collateralized Debt Obligations (CDOs), and Credit-Default Swaps (CDSs), and the quality of banks' loans are not easily discernable by third parties, Peter O. Mülbert (2010) emphasized on ambiguity of their balance sheets rather than those of other companies.

6. Banks do a major part business with their own competitors, other banks. To banks, hence, competitors are also their business collaborators that it leads into a major counterparty risk. In other words the problems of one bank rapidly spread to other banks and banking system [6]. 
7. Peter O. Mülbert (2010) discuss: "In contrast to the typical non-financial firms, a bank holding a substantial portfolio of derivatives and securities with embedded options is subject to sharp changes in its risk-profile even if the bank does not take new positions."

He continues because complex derivatives are exposed to risk factors and market conditions, even incremental changes on the market may influence the value of the derivatives and change it drastically [6].

8. Because of the mismatch in the term structures of assets and liabilities, banks are subject to creditor runs [6].

9. The last characteristic related to probability of bank run as if lots of bank or other financial institution's depositors withdraw their money concurrently because of their concerns about firm's bankruptcy. In this regard Peter O. Mülbert (2010) expresses that:

"Because of their systemic importance on the one hand and their vulnerability to runs on the other hand, banks are heavily regulated and supervised entities".

All above specific characteristics requires considering an appropriate model for corporate governance of banks emphasizing management of operational, liquidity, credit and other risks.

\section{Methodology}

\subsection{Research Questions Development}

Current occurrence of some problems in Iran banking system has been attracted attentions towards the main causative factors and how to deal with them. Investigation of experiences in all around the world shows that other countries have been dealing with this kind of problems and they have been able to successfully pass the crises. It can be expressed that existence of desirable corporate governance model would prevent banks from encountering such these problems.

Therefore, we can categorize the research questions as follows:

Main Question:

What is an appropriate corporate governance model for Iranian banks?

Sub Questions:

1. What is the current state of corporate governance structure in Iranian banks?

2. What is the successful corporate governance model in prosperous banks in all around the world?

3. What are the weaknesses of the current corporate governance model in Iranian banks?

4. Considering the conditions of banking industry in Iran

\subsection{Research Method}

In the light of goal, this research is applied and in the light of method, it is analytical. Based on research questions detailed in previous section, the research shall be done in several phases as follows:

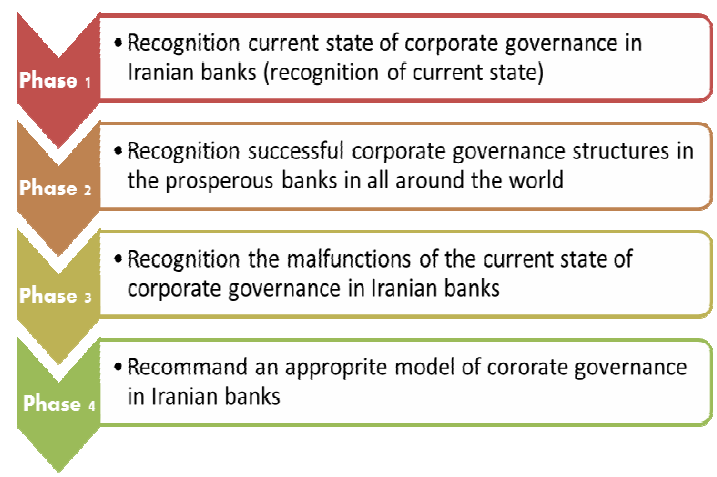

Figure 1. Research phases.

Among above phases, the first and second one would be done via archival method and reviewing existent documents and records regarding corporate governance in Iranian banks and International prosperous banks. Furthermore, the third and fourth phases would be done via comparative analysis and using national and international experiences regarding corporate governance model.

\subsection{Data Collection}

In order to collect required data for corporate governance of Iranian banks, we use three methods including reviewing directives and instructions of CBIRI, interview and observation. To interview, firstly, we prepare a checklist based on requirements of CBIRI and all existent corporate governance mechanisms of prosperous banks in the world including Bank of America, Toronto-Dominion Bank, J. P. Morgan, and HSBC. This checklist consists of 159 phrases in 6 following overall sections:

a) Board of directors;

b) Board committees;

c) Chief executor officer (CEO);

d) Audit committee;

e) Compensation committee;

f) Risk management committee;

g) Other matters.

However, to obtain a comprehensive overview toward the current state of corporate governance in Iranian banks, it is much better to apply Semi-structured interview enabling researchers to ask other questions, if needed, beyond the checklist. On the other hand it is required to select those persons who have job experience in banking industry and in different positions for several years to have adequately enough information regarding variant aspects of corporate governance in banking industry. Respecting mentioned considerations and inherent limitations for having access to banks' authorities, researches succeeded to interview with 16 persons in some positions such as executive management, board of directors, internal auditing and advisors in Iranian public and private banks. On the other hand, we review banks' information on the net and reports of the board of directors' performance to make sure that we have obtained comprehensive view about subject. 


\section{Findings}

Before describing corporate governance of Iranian banks, it should be noted that CBIRI, as a banking supervisor, often provides Iranian public and private banks with guidance of Basel Committee on Banking Supervision and requires them to use instructions of Committee as a reference point to consider suitable corporate governance mechanisms. CBIRI, also, always attempts to necessitate relevant instructions to reform the state of Banks' corporate governance. But the problems are:

1. According to investigation of the existent state of corporate governance of Iranian banks in this research, we find out there are some inconsistencies between CBIRI requirements and what banks implemented;

2. CBIRIB overlooks some substantial practices adopted by prosperous international banks.

So in this section, rather than describe total practices of corporate governance in banks, we try to present those main points which lead to malfunctions.

\subsection{Board of Directors}

\subsubsection{Board of Directors Membership}

According to the Bylaws the range of five to nine directors for the Board is appropriate and they are elected at the annual meeting of stockholders. Election of members and extension of their tenure are subject to the approval of their professional qualifications by CBIRI. It is notable that candidates can be recommended by directors, management, and stockholders.

\subsubsection{Limits on Board and Audit Committee Memberships}

The term limits for director tenure is 2 years. There is no limitation for the age of directors. Each director is permitted to serve on the numerous boards of other publicly owned corporations (without any limitations).

\subsubsection{Performance Evaluation}

Board performance is evaluated periodically while there is no necessarily coherent and pre-determined plan.

\subsection{Committee Matters}

\subsubsection{Board Committees}

The primary Board committees include audit committee and risk management committee. The Board may establish additional committees such as compliance committee, as it consistent with the bank's Bylaws and applicable laws or regulations.

\subsubsection{Assignment and Rotation of Committee Membership}

All members of Board committees are not necessarily independent and non-executive. Committee membership is reviewed by the Board and it has no strict committee rotation policy. Committee chair positions are approved by the Board.

\subsection{Duality}

In fact, in public banks CEO can simultaneously hold the position of chairman of the Board. However, based on CBIRI instruction, private banks are forbidden to assign the position of the Board to the CEO.

\subsection{Audit Committee}

\subsubsection{Membership}

The following items are provided in connection with the characteristics of the members of audit committee which are not necessarily complied by all banks:

1. The committee shall consist of 3 members out of the Board;

2. All committee members shall be financially literate;

3. At least one member of the Committee shall be deemed an "audit committee financial expert".

\subsubsection{Duties and Responsibilities}

According to the collected data, following items are presenting the committee duties and responsibilities, but it should be clarified that all of them are not necessarily observed in all banks:

- Review measures taken by management in order to resolve any material malfunctions and weaknesses reported in external audit report;

- Review and discuss with management, internal and external auditor audited consolidated financial statements and the results of annual auditing;

- Discuss with management, internal and external auditor effectiveness of internal controls;

- Discuss with management, internal and external auditor new or proposed accounting standards;

- While consolidated financial statements are of the ultimate management responsibility, committee are responsible of planning and coordinating of annual auditing;

- $\quad$ Receive and approve the annual internal auditing plan;

- $\quad$ Receive and review periodic internal auditing reports from management;

- Review with management, internal and external auditor any correspondence with legislators and governmental agencies;

- $\quad$ Discuss with management and corporate legal lawyers the nature and state of material legal and regulatory matters;

- Supervise implementation of code of ethic by management and all personnel.

\subsubsection{Committee Authorities}

With management coordination, the Committee shall have full access to any relevant records and documents of the Company. The members also don't have any limitation for membership to audit committees of other companies.

\subsubsection{External Auditor}

Based on Bylaws, external auditor is selected at the annual meeting of stockholders; audit committee doesn't 
have any contribution in this regard. It should be noted that external auditing of public banks are done by Auditing Organization of Iran; however, an institution, the member of Iranian Institute Certified Public Accountants, does external auditing for private banks.

\subsubsection{Audit Fee}

According to the Bylaws the Board shall approve retention of the external auditor as well as type and estimated fees of the audit and non-audit services.

\section{Discussion: The Appropriate Model for Corporate Governance in Iranian Banks}

In this section, by using the collected information regarding the current state corporate governance in Iranian banks and by comparing them with the prosperous cases across the world, we are attempting to seek an optimal model for Iranian banks.

\subsection{Board of Directors and CEO}

Board of directors, as a significant element, carries out the final responsibility of the bank business, strategic risk, and financial stability as well as organising and managing of the bank. Besides implementing the mentioned roles, creditable banks across the world have designed and applied some mechanisms which are either not seen or undervalued in the guidelines, requirements and the directives of Iranian banks. Such as:

- Directors and CEO qualifications and selection

- Directors independency evaluation

- $\quad$ Limiting the activity of the Board's members

- $\quad$ Performance evaluating of the board's members

\subsubsection{Directors and CEO Qualifications and Selection}

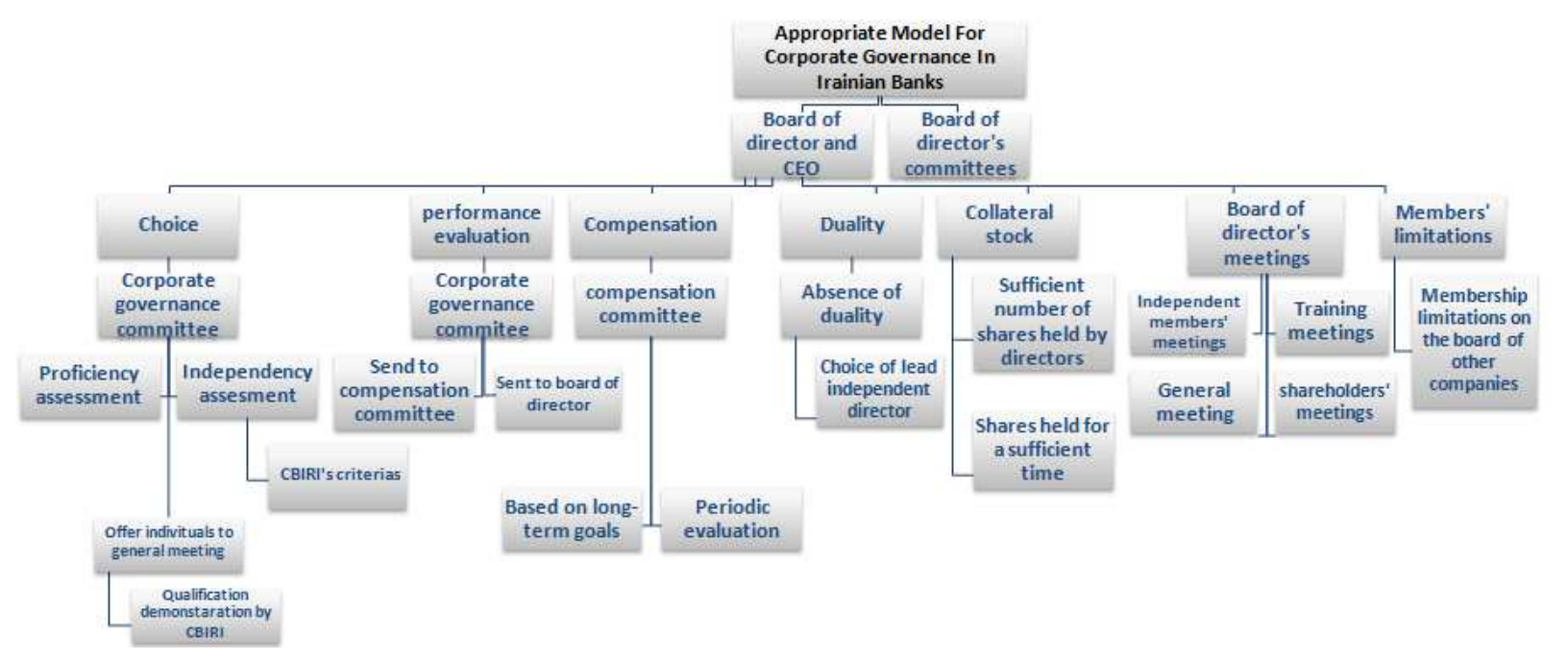

Figure 2. Board of director and CEO model.

According to the "The guideline of professional qualifications and disqualification of chief executive manager and the members of the board", Iranian banks require CBIRI approval on directors and CEO candidates to select or reselect them. While, at pioneer banks including Bank of America, this operation is carried out by corporate governance committee and in consultation with the Board of directors.

Therefore, since the issue of the appointment and the qualification of the nominees in the light of their competency and independency in for best handling of monitoring and controlling on behalf of both the Board and CEO is highly critical, it is suggested that by forming the committee of corporate governance, which scrutinises the qualities of the nominees from all aspects, the whole process of appointing will definitely be elevated to a systematic process. Moreover, this committee is in charge of periodic reviewing of the selecting criteria and standards of the Board's members.

In the recommended model in this research, in addition to considering the present legal restrains in Iran's banking conditions including CBIRI engagement in this process, the enhancement of the selection process has been taken into account through specialised reviews of corporate governance committees in the field of independence and proficiency.

\subsubsection{Directors Independency Evaluation}

Based on Committee on Banking Supervision Basel (2010), Board of directors should vigorously perform their responsibilities such as publishing the strategy of risk and business, organization, financial stabilizing, and also the committee should provide an effectual supervision on senior management. Consequently, Independency is considered as a highly significant factor in corporate governance as if the related standards are directly useful in order to perform the qualifying process.

In all distinguished banks of the world, corporate governance committee is in charge of making annual evaluations of the directors' independency. Also, the 
presence of the Lead Independent Director is a sign of the importance of independence in the decisions and the corporate governance mechanisms in banks.

The investigation in this paper suggested that even though there is an act concerning the independency criteria of managers and the Board members for admitted companies in Tehran Security Exchange; only some (or a few) banks of Iran are as corporations and are legally responsible for obeying this act. Thus, it is expected that The CBIRI, as a supervisor institution of banking industry, set out to define the independency qualities of the managers and directors specifically for this industry.

On the other hand, there is CEO duality issue in Iranian public banks; while in pioneer banks, in the case of encountering this issue, one of the board's members would be appointed as the Lead Independent Director to supervise the process of decision making. Thus, it is suggested that if the separation between the CEO and the Board chairman is impossible, then appoint this person as a practical method to prevent Board from independence impairment.

\subsubsection{Limiting the Activity of the Board's Members}

Reviewing the models used by the prosperous banks over the world suggests that the members of the board at the foreign banks are subject to some restraints such as not serving in other positions in other companies or banks and even the same goes for maintaining the shares of the bank's common stock which they are working in- as collateral.

Based on this paper investigations, it seems that these bans are needed to be reconsidered in some cases, for example, The members of Boards in Iranian banks are legally prohibited just in the case of becoming the member of other banks' Board, while, this does not extend to the membership at other companies. Therefore, we suggest that, according to the models of most creditable international banks, becoming the members of other companies should also be included in the rest of the restriction as well. This will probably not only contribute to the alignment of the interest among the members of the Board and their banks but also motivates them to assign more time attending the meeting of the Boards actively and making them more effectual.

On the other hand, according to the Bylaws of private banks, each member of the board is required to own at least 10,000 shares of common stocks of the bank ,to keep it during his/her tenure and to deposit it into the bank as pledge. These shares are preserved to guarantee any loss that the bank may suffer due to the faults of the directors, whether it is inflicted individually or by a number of them. However, this amounts for prosperous banks such as Bank of America, which is claimed not to be for compensating the loss but to align the interests of the directors and CEO with those of the bank's shareholders, exceeds to at least 500,000 shares of the common stocks for CEO and 300,000 shares for each of the executive managers that at least $50 \%$ of them (after tax) should be held until retirement. Evidently, the amount of shares is far smaller in Iranian banks than the successful samples in around the world.

Firstly, using the phrase:" guarantee for any possible loss" does not convey a positive meaning, so replacing it with "alignment of interest", categorically, makes the phrase feel smoother and comes to CEO and other managers' mind that they are considered as stakeholders. Secondly, it is also suggested that the level of shares ownership to be matched with the size of the bank not set on a fixed number, so that it can prevent any conflict of interests.

\subsubsection{Performance Evaluating of the Board's Members}

Enquiring the current state of the corporate governance of Iranian Banks, it was found that contrary to the other mentioned items concerning the Board of directors and its members, and CEO, no particular instruction for performance evaluation of the CEOs and directors has been published yet. This can again highlight the absent of the corporate governance committee in Iranian banks, while in pioneer banks around the world, the committee is liable for this task. In addition, the other key element, which is arranged in an impressive way, is the communications between various committees to accomplish the evaluation. In a way that compensation committee uses the performance evaluation results of the corporate governance committee in the policy making.

Since no particular procedure in evaluating the performance has already been developed as corporate governance of Iranian banks, in the appropriate model suggested in this research, it has been struggled to exploit the performance evaluation reports in the best way, and also to leave the most drastic effect on the performance of individuals, by taking the service of the both committees of corporate governance and compensation into account.

\subsection{Board Committees}

\subsubsection{Types of Committees}

Currently, Iranian banks' Board take advantage of audit committee and the risk management committee, and formation of any extra committees is subject to compliance with the bank's Bylaws including the compliance committee. Pioneer banks, however, are served by a large number of committees such as: nomination, compensation, business, corporate sustainability, credit and human resource committee. The responsibilities and duties of the mentioned committees have clearly been outlined with details in their charters.

It is suggested that based on above reasoning and costbenefit analysis and considering all the responsibilities and duties of each of these committees, the CBIRI spreads the requirements to let the banks enjoy similar committees too. 


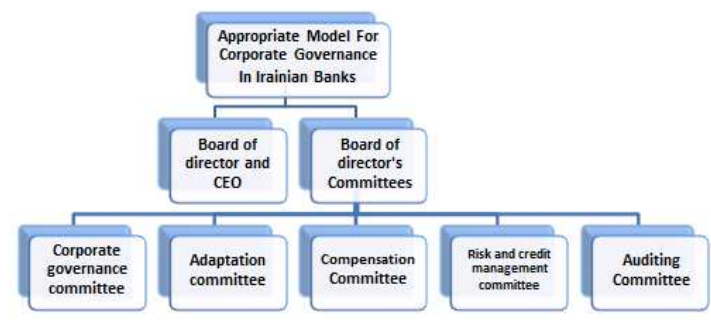

Figure 3. Board committees.

In the next section we are going to expand on the importance of the risk and credit, corporate governance and compensation committees, and the arguments of the researchers will be indicated in details.

\subsubsection{Circumstances and Rotation (or Replacement) of the Membership in the Board of Directors}

Based on the stress of the Basel committee (2010) on refraining from unnecessary centralization of power and also, enhancement of novel viewpoints, members and the directors of the board must be replaced periodically, and it should be done in a way that the group skills and experience and the efficacy of the committee is not trampled. According to the performed inspections in Iran, it was established that there is no coherent and regular plan to revise the memberships and also no defined rotation policy for the membership of the committee. However, in prosperous banks in around the world including bank of America and J. P. Morgan, corporate governance committee is responsible for periodic review and revise of the board's membership.

Hence, it is suggested that in order to assure a proper combination of skills and experience in every single committee and to receive the optimised output, a detailed and prospective plan develops in which the point such as the policy of circulation is considered as well.

\subsection{Audit Committee}

Audit committee as one of the mechanisms of corporate governance has played an important role in governance of the companies ever since its advent in the first 1940s. The recent financial scandals have made its existence more crucial indeed.

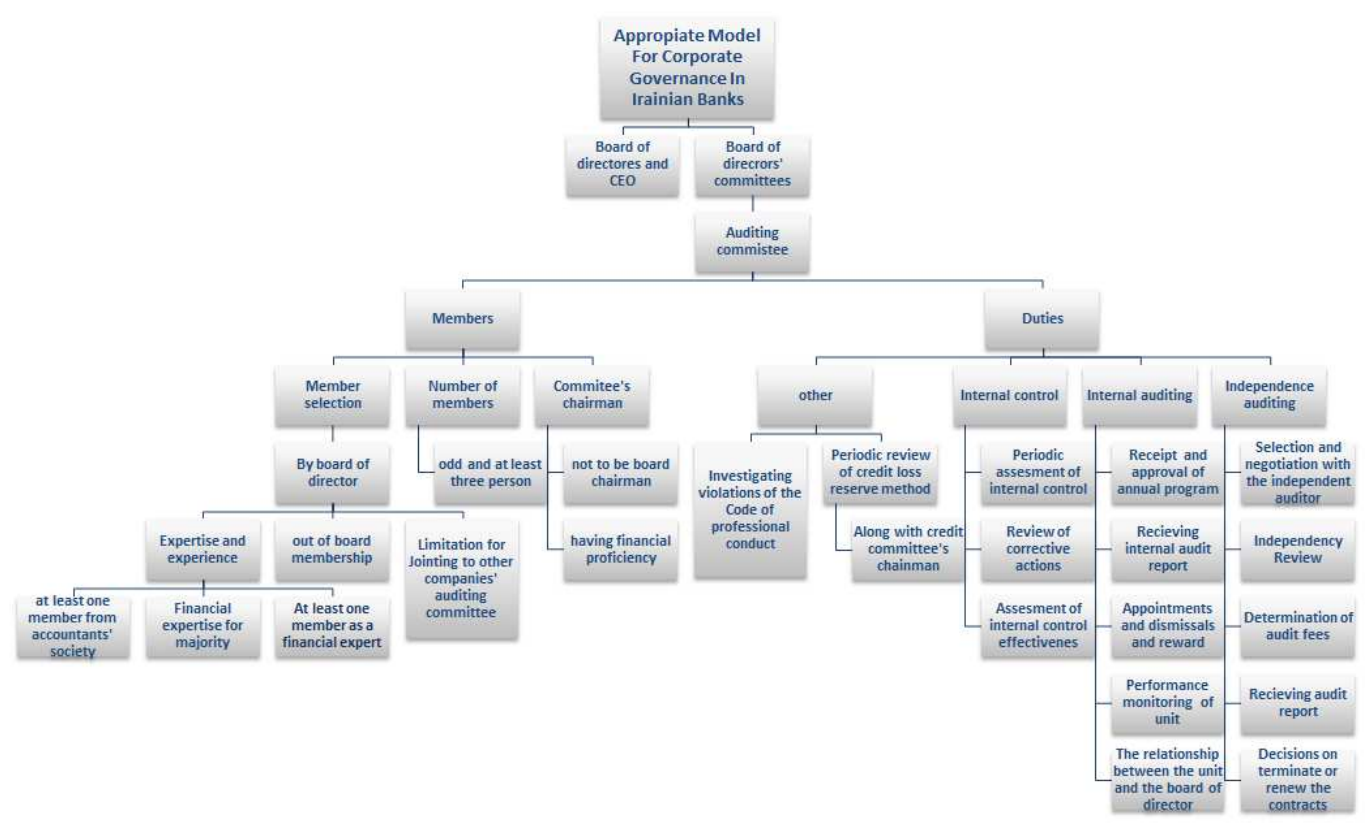

Figure 4. Audit committee model.

Audit committee in all giant banks including Bank of America, Toronto-Dominion Bank, is liable for employing, determining the compensation, firing or dismissing the external auditors, checking and approving the auditing scope, the frequency of auditing and receiving audit reports It should be noted that the 2006 version of Basel Committee on Banking Supervision guidance, which this point has clearly been stated in that, has been translated in Persian by the CBIRI and it has been compulsory for public and private banks. However, based on public and private Iranian Banks Bylaws the external auditor is elected at the annual meeting of stockholders and compensation and dismissing of audit institution are the authorities of these meetings and these are out of the power of the audit committee.

It gives rise to two issues:

1. The differences between the procedures of Iranian banks and the credible banks throughout the world; and,

2. Discord between the requirements of the CBIRI (the gap between the text of the Bylaws and what was translated from Basel's guidance) which

Leads to disorganization in practice. Thereby, it is recommended that the appointments, compensation determination, termination or renovation of the contracts with the external auditor, and reception of audit reports all to be handled by the audit committee, in order to proceed 
towards removing the ambiguities and inconsistencies.

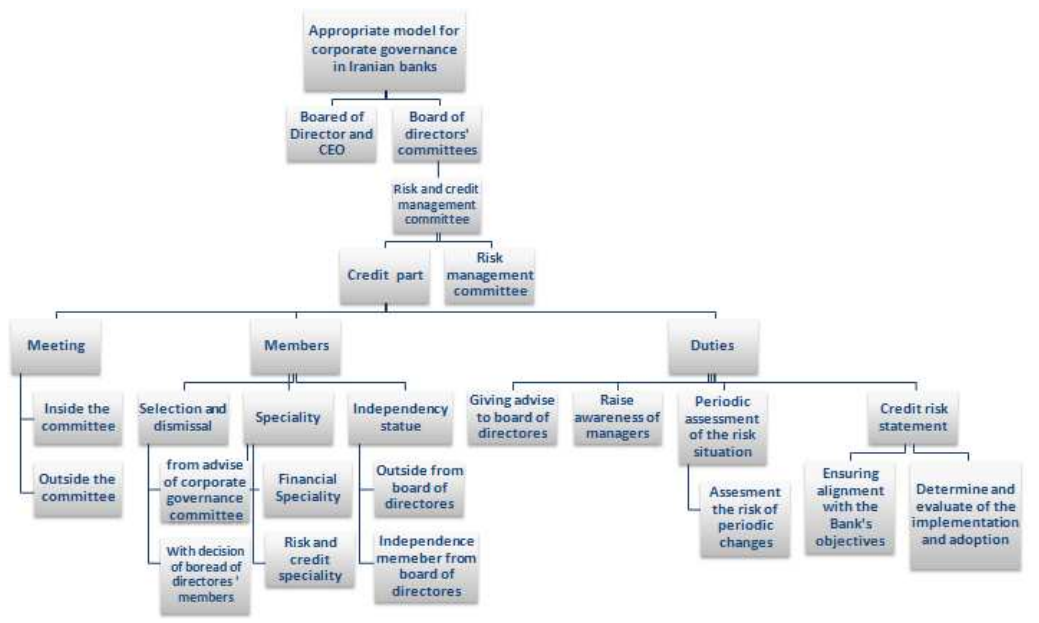

Figure 5. Risk and credit management committee model.

More to the point, given the supervising role of audit committee, which facilitates the relations between internal auditor and the management, and the final duty of execution, preservation and improvement of internal controls is of the management's responsibilities, it is better that the audit reports to be sent directly to audit committee so that it prevent any negligence for prompting the quality of internal controls and eliminating the weaknesses. Findings show that in Iranian's bank, the auditor reports are not submitted directly to the committee and they are later handed in them by the management, while in pioneer banks over the world including Bank of America, the internal auditor is bound to submit the report directly to the auditing committee.

Comparing the tasks and responsibilities of the audit committee between Iranian banks and the reputable banks of the world, it was established that the responsibilities and the tasks of this committee in Iranian banks are not enough consistent and comprehensive. Of course, it must be mentioned that sometimes committees don't execute all their responsibilities in all banks. So in order to give assurance to the effective execution of the audit committee roles, optimum performance and beneficial presence of this committee in all Iranian banks, it is suggested that the CBIRI reviews the duties and responsibilities of this committee radically. In the following figure, we are trying to represent critical responsibilities of audit committee.

\subsection{The Recommended Committee of Risk and Credit Management}

Given the importance of evaluation and risk management, it should be stated that the activity and the survival of the banks depends on the sound appraisal of variety of risks including the most important ones in financial and credit institutions is the credit risk. This operation is done through some committees naming "risk and credit committee" or with other similar titles across the world. Investigations indicate that there has been nothing speculated in this regard in Iranian banks and it is characterised by enormous amount of deferred bank accounts and occurrence of giant embezzlements in country's banking system.

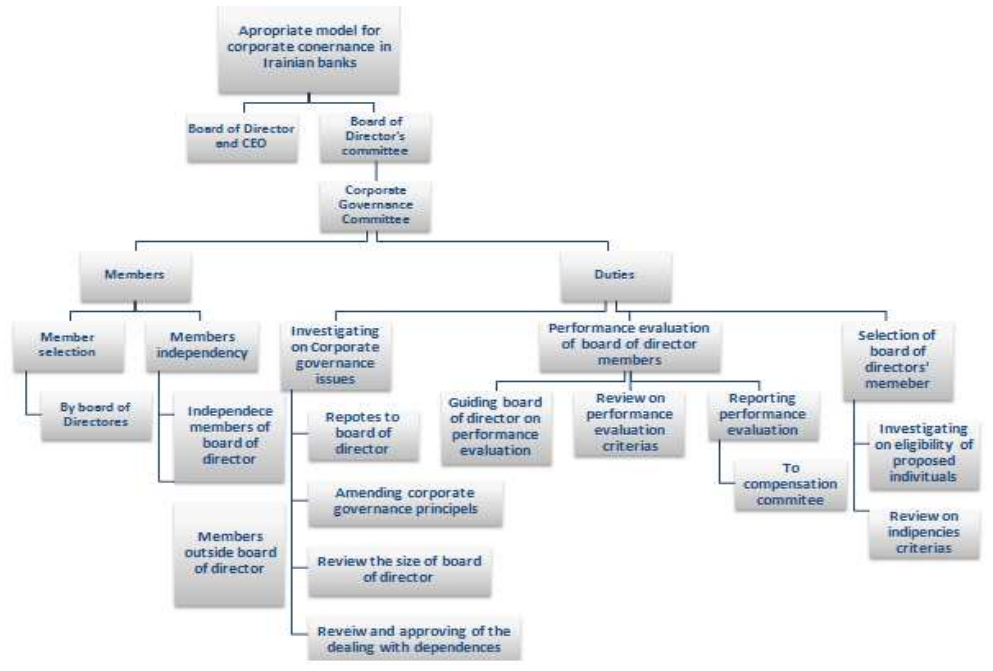

Figure 6. Corporate governance committee model. 
Based on investigation in this field, it was established that the committee of risk management in Iranian banks burden the tasks of evaluating the current state of risk in banks and bank's risk-taking, assessing the performance of management inside the predefined level of risk appetite and representing related political and controlling systems. However, according to the importance of credit risk in bank industry, it seems that the formation of credit risk management unit inside the committee of risk management is necessary in order to reduce the risk. The responsibilities and the tasks of the mentioned unit will be outlined later in this paper (Figure 5).

Furthermore, the members of this unit shall be selected just from independent members of the Board and those who are outside of the board. These people should be specialised not only in the area of financial affairs but also in the field of risk and credit. They should also be able to perform their assigned duties through attending the constant meetings inside the committee and with other committees.

\subsection{The Recommended Corporate Governance Committee}

Many believe that the most primary base of corporate governance is the board of director and the related issues. Along this, based on the enquiries made into the mechanisms existing for selecting the board's members and for the evaluating policy of their performances at prosperous banks across the world, the void of this committee in the structure of Iranian banks' corporate governance could be felt. Even though it should not be neglected that the CBIRI as a supervisor institution has penetrated deeply in plenty of the banking mechanisms such as the procedure of qualification and selection of the Board's members and separating some of those from this institution are virtually not applicable. .

Therefore, by taking the current condition of laws and regulation of Iranian banks into account and also the present of CBIRI as a Supervisor institution, it is suggested that corporate governance committee and specific responsibilities and duties mentioned in appropriate model should be established. The members of this committee shall be chosen among individuals outside of the Board or among independent members of the Board.

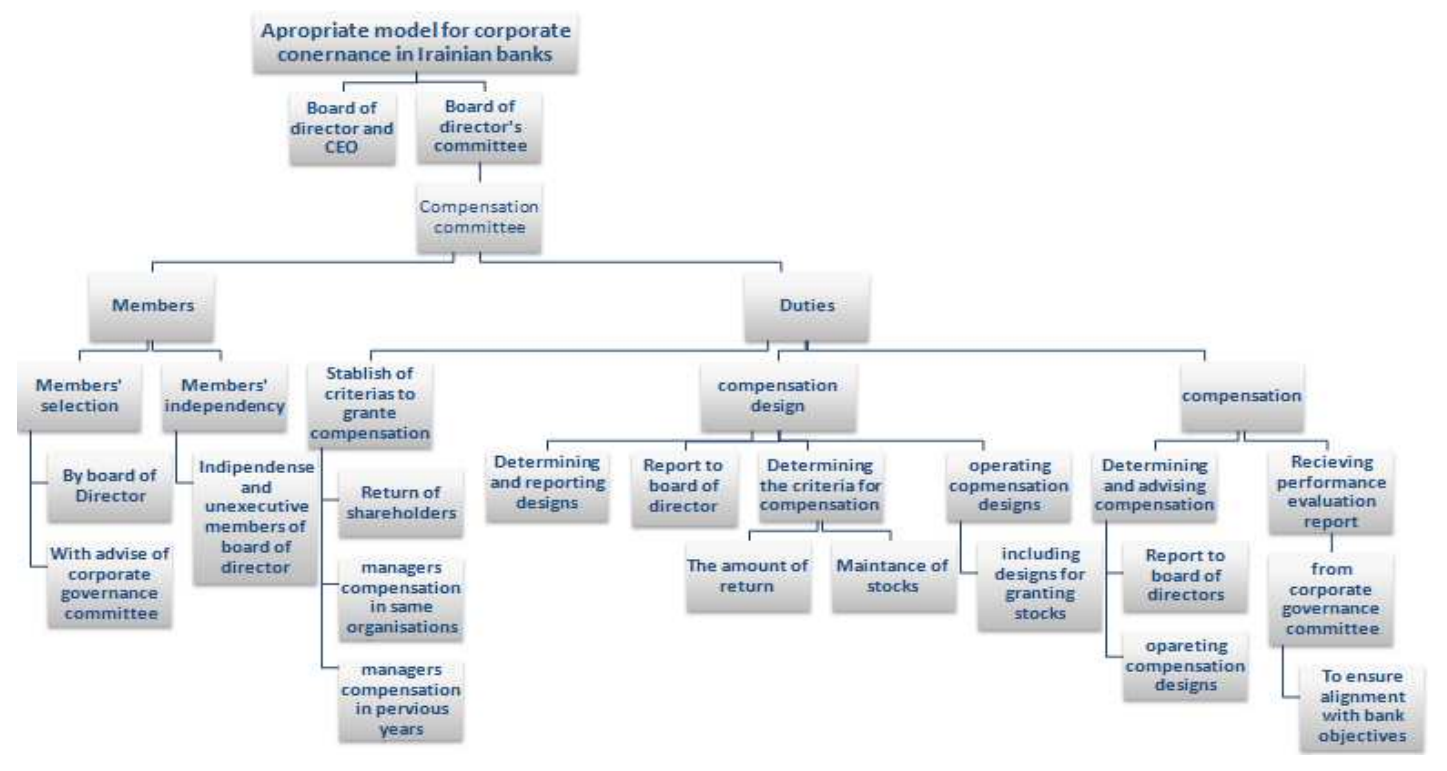

Figure 7. Compensation committee model.

\subsection{The Suggested Compensation Committee}

The issue of the way and the amount of compensation and the bonus has always been of controversy and importance among members of the Board. The importance of this matter arises from the impact of compensation granting method on the conflict of interests between the company and the managers, the future performance and consequently profit making of the company. Therefore, it is crucial to consider the long-term goals and the strategy of the company for granting the compensation.

Most of the prosperous banks of the world such as HSBC and Bank of America enjoy the compensation committee in defining the policies of compensation. This committee decides the main strategies regarding the paying criteria and long-term motivation plans and finally provides the board with some suggestions.

Considering the critical role of the committee in the company, it is suggested that the CBIRI devises the needed measures in this regard and requires the banks to form this committee. It is also suggested that according to the models of compensation committee in prosperous banks of the world, the number of committee members shall include the independent and non-executive members. The appointment and dismissal of the head and members of the committee shall be done by the Board and suggestions of the corporate governance committee, as well. 


\section{Conclusion}

In recent economy crises, one of the main factors that have always been convicted is the weakness of corporate governance in banks. Investigating the global economy turmoil has attracted the attentions towards the betterment of the faults and imperfections existing in this system. Besides, considering the qualities and the attributes of the banks, which has made them distinguished from other companies, is highly significant. The vast variety of banks stakeholders, the complexity and the ambiguity of banking business and the gap between the maturity of the assets and the debts, are of the outstanding qualities of this industry which has beside making them specific, caused their activities to be exposed to plenty of risk such as operation, credit, liquidity, etc.

In this paper, by considering the value of corporate governance in banks, the different nature of banks from other industries and successful corporate governance models in prosperous banks, we have tried to investigate the flaws existing in Iranian banks' corporate governance. And even by emphasising on the vulnerability of the banks as the result of dealing with several different risks and consequently how to manage them, we have offered an appropriate model for the corporate governance in Iranian banks. Accordingly, this research has been carried out by utilising various measures like questionnaire, interviewing with professors and experts around the related field and also by studying the related texts.

The results suggest that the current system of corporate governance in Iranian banks suffers from lacks in various fields that have led to poor results in performance of banks. with respect to the members of the boards and the CEO, there are imperfections in the way of qualifying and selecting of the members of the board and CEO, the way of evaluating the independency of board' members. The faults and imperfections in this regard are mostly involved in field of the processes and the institutions that in this paper have been tried to be hinted through bringing examples of prosperous banks of the world. Including of the suggested models are the introduction of the independent committee of board of director in the process of performance evaluation of the board and CEO called as "corporate governance committee" and inducing motivations through amount of compensation aligned with the performance that shall be handled by other independent Board committee as compensation committee. Formation of credit unit in risk management committee has been emphasized to ensure effectively credit risk managed.

Including of the most important sphere that has been scrutinised is the committee of the board of director. In this regard, the existing committees of the current banking system in Iran, such as auditing committee, risk committee and compliance committee have been investigated through the mentioned research instruments, and modifications have been suggested regarding to their successful counterparts in the world. For instance, the modification of the responsibilities of the auditing committee has been inspected.

\section{References}

[1] Alexander, Kern, "Corporate Governance and Banking Regulation”, CERF Research Program in International Financial Regulation, 2004.

[2] Basel Committee on Banking Supervision, "Principles for enhancing corporate governance", 2010, 2006, 1998.

[3] Kirkpatrick, Grant, "The Corporate Governance Lessons from the Financial Crisis", Financial Market Trends, 2009.

[4] Marcinkowska, Monika, "Corporate Governance in Banks: Problems and Remedies”, National Science Centre, 2012.

[5] Mehran, Hamid, Morrison, Alan, Shapiro, Joel, "Corporate Governance and Banks: What Have We Learned from the Financial Crisis?" Federal Reserve Bank of New York Staff Reports, no. 502, 2011.

[6] Mülbert, Peter O, "Corporate Governance of Banks after the Financial Crisis: Theory, Evidence, Reforms". http://ssrn.com. 2010

[7] Rezaee, Zabi, "Corporate Governance and Ethics", Wiley, 2008. 